\title{
Impact of Infrastructure on Foreign Direct Investment in Nigeria: An Autoregressive Distributed Lag (ARDL) Approach
}

\author{
Joshua Adeyemi Ogunjimi* Benjamin Olorunfemi Amune \\ Department of Economics, University of Ibadan, Nigeria
}

\begin{abstract}
This study examines the roles infrastructure play in attracting foreign direct investment (FDI) into Nigeria for the period between 1981 and 2014. It also investigates the type of infrastructure that has more impact on FDI attraction. The unit root test results show that none of the variables in the study is integrated of order two, that is, $\mathrm{I}(2)$, a condition which justifies the use of Autoregressive Distribution Lag (ARDL) framework. The ARDL Bounds Test approach to cointegration was employed to determine the long-run relationship among the variables in our model and the result shows that there is a long-run relationship between infrastructure and FDI in Nigeria. The result of the estimation of the selected ARDL Error Correction Model shows that none of the infrastructure variables (tractor, telephone lines and electricity) employed in this study is significant to attract FDI into Nigeria in the short-run although electricity production (power supply) was found to influence FDI in the long-run. The study thus recommends that the power sector be revitalized and should be given priority as it will attract FDI, increase national output and move Nigeria closer to actualizing her dream of becoming one of the twenty leading economies in the world by the year 2020 .
\end{abstract}

Keywords: Foreign Direct Investment, Infrastructure, Nigeria, Autoregressive Distributed Lag (ARDL). DOI: $10.7176 / \mathrm{JESD} / 10-3-01$

\section{Introduction}

Every country of the world, especially developing economies, strives to attract foreign direct investment (FDI) because it is a major source of external finance. FDI affords countries with little capital the opportunity to get finance from wealthier countries. Many experts opine that foreign direct investment (FDI) has the capability of speeding up the economic growth process of developing countries (Obiwona, 2001). There are inexhaustible benefits associated with the inflow of FDI that are put to optimal use among which are the opportunity it affords developing countries to have access to modern technology and key administrative ingenuity which are capable of increasing domestic output, creating more jobs, lowering cost of production and raising workers' wages (Cohen, 2007).

Furthermore, FDI has been arguably one of the means through which external capital is sourced to augment domestic savings in a developing country owing to the inadequacy of the financial and capital market to finance the various sectors of the economy (Adeoye, 2009). In addition, FDI plays a pivotal role in helping developing economies access the foreign markets on behalf of its people (Obiwona, 2001). Summarily, the proponents of FDI opine that it contributes positively to its recipient's economy through the supply of technology, capital and management wherewithal that are unavailable in the host country as well as creating jobs that would otherwise not be created there (Hill, 2003). It is thus apparent that FDI is important in a country to bridge resources gap, savinginvestment gap, technological gap, revenue-expenditure gap, and output/export gap, among others. The aforementioned benefits of FDI are crucial for sustainable economic growth in developing countries.

However, the extent to which a country attracts FDI is a function of many factors which include: labour costs, market size, profitability expectation, human capital, FDI policy, and infrastructure, among others. Many studies have identified infrastructure as the major of source of FDI inflow. Chakrabarti et al (2012) discovered a positive relationship between infrastructure and FDI inflow. Also, Omezzine (2011), and Hakro (2011) discovered that governance infrastructure affects FDI flows significantly.

The availability of infrastructure promotes FDI because it reduces operational costs. Seetanah (2009) claimed that gains resulting from infrastructural development are closely linked with greater accessibility and a decrease in the cost of transportation. He further argued that the availability of public goods reduces the cost of doing business for foreign companies thereby leading to profit maximization. Recent studies also assert that the availability of public goods plays a crucial role in determining the structure of cost and productivity of firms in the private sector (Bénassy-Quéré et al, 2007). Also, Erenberg (1993) asserts that domestic and multinational companies will operate with less efficiency and below their optimal level should public infrastructures not be extended to them because they would have to incur an additional cost of building infrastructures of their own and this will lead to duplication and wastage of the available scarce resources. The study thus, concluded that public infrastructures reduce the cost of transportation.

However, the major problem to Nigeria's low level of FDI attraction is primarily due to low level of savings and investment in infrastructure. The situation of Nigeria is such that the few available fixed assets (infrastructures) are in deplorable states, unemployment rate is on the increase, exchange rate depreciates incessantly, persistent 
fall in crude-oil price in the international market and a relatively high monetary policy rate (interest rate), among others. These discourage local investors from borrowing, hinder investment and incapacitate government from fully executing capital projects.

Nigeria's quest for economic growth and development lies primarily in the attraction of Foreign Direct Investment (FDI). In recent years, the attraction of foreign direct investment has gathered impetus as the Nigerian government is spending large sums of money on infrastructures so as to attract foreign companies into the country. This effort is manifested in the signing of eleven (11) Double Taxation Treaties (DTTs) and six (6) Bilateral Investment Treaties (BITs) so as to encourage FDI inflow to Nigeria. The Nigerian government understands that, in order to attract attracting Foreign Direct Investment, it is needful to invest in infrastructure which will promote a sound macroeconomic environment in Nigeria.

The Nigerian government has put in place a number of infrastructural institutional frameworks overtime to help in the development and sustenance of infrastructures in Nigeria. They include: The Infrastructure Concession Regulatory Commission (ICRC) which is charged with the responsibility to develop and issue guidelines on Private-Public Partnership (PPP) processes, policies and procedures, and to serve as a national centre of expertise in PPP; The Private-Public Partnership Resource Centre which comprises personnel with backgrounds in finance, law and public administration saddled with the responsibility of providing the expertise for implementing PPP projects across the sectors of the Nigerian economy; The National Planning Commission which is charged with the responsibility of preparing the federal government's National Development Plan in line with the sectoral plans of the Ministries, Departments and Agencies (MDAs); MDAs are in charge of the management of public infrastructures, services and their own resources; and the Infrastructure Policy Commission's objective is to facilitate the adoption of various Nigerian Economic Society's recommendations with a view to fast-tracking growth and development of the economy, among others.

Furthermore, different policies have been made at different points in time to ensure acceleration of infrastructural development and sustainability. The policies include: The Nigeria Integrated Infrastructure Master Plan (NIIMP) which is a 30-year master plan aimed at fast-tracking infrastructural development in Nigeria with its focus on fundamental infrastructures like energy, water, transportation, housing and ICT; The National Telecommunication Policy (NTP) which seeks universal accessibility and cost-effectiveness of telecommunication services in Nigeria; the National Water Supply and Sanitation Policy (NWSSP) which is aimed at making safe water and sanitation easily accessible to Nigerians at affordable prices; and The National Rural Water Supply and Sanitation Program (NRWSSP) which has the overall goal of consolidating, increasing and sustaining universal accessibility to sufficient quantities of cheap but safe water by 2015 together with hygienic sanitation facilities by 2020, among others.

The Nigerian public officials as well as state governors and federal ministers frequently visit developed countries of the world such as USA, Australia, Europe, China, Canada, Japan and South Korea to implore foreign organizations, government and individuals to invest in Nigeria promising to give them incentives like tax incentives, low interest loan, grants, and increasing government expenditure on infrastructure, among others. It is against this background that this study's primary objective is to empirically investigate the impacts of infrastructure on foreign direct investment inflow to Nigeria from 1981 to 2014. Specifically, it determines if there exists a long run relationship between infrastructure and FDI inflow in Nigeria or if these two macroeconomic variables converge in the long run.

\section{Literature Review}

There are myriads of studies conducted on the relationship between infrastructure and foreign direct investment (FDI) for different countries of the world. The objective of the studies was to investigate or examine the relationship between infrastructure and FDI as well as how this relationship influences economic growth. Attraction of foreign investment is not an end in itself but a means to an end as its ultimate goal is to achieve economic growth.

Chakrabarti et al (2012) examined the relationship between infrastructure and FDI in India between the year 2002 and 2007. The study aimed at investigating the effects of infrastructure on FDI inflow. The results showed that there is a considerable variation in the level of public infrastructure in 2001 among the various Indian states together with the FDI inflows between 2002 and 2007. They also discovered that there is a positive relationship between physical infrastructure and FDI inflow. However, FDI inflow was found to remain insensitive to changes in infrastructure till a threshold is reached after which it increases steeply with an increase in infrastructure. The result also showed that there is a non-linear positive relationship between physical infrastructure and FDI inflows.

Behname (2012) used cross-sectional data of Southern Asia countries between 1980 and 2009 to investigate the effect of urban infrastructure on FDI and found out that urban infrastructure impacts FDI positively and recommended that the governments in the southern Asia countries give priority to infrastructural development for FDI attraction.

Fung et al (2005) sourced the data used for their analysis data from China Foreign Economic Statistical 
Yearbook 1994 and Almanac of China Foreign Relations and Trade to examine which type of infrastructure (hard or soft) draws the attention of foreign investor and attracts FDI to China. The empirical result of the estimation of the regression model shows that both soft and hard infrastructure have a significant positive effect on FDI inflow although soft infrastructures persistently outpace hard infrastructure in attracting FDI. It was found that soft infrastructure is the most important element in attracting FDI to China. The result implies that initiating and implementing market reforms (soft infrastructure) have more positive significant effect on FDI attraction than constructing more hard infrastructures like roads and railways.

Making use of time series data for the period 1981-2005, Seetanah (2009) carried out a panel study aimed at examining the link between FDI and transport infrastructure in Mauritius with a view to investigating the role of transportation infrastructure in attracting FDI to the manufacturing and services sector of Mauritius. The result of the estimation showed that both non-transport and transportation infrastructure are important determinants of FDI inflow to the sectors of the Mauritius economy. However, the manufacturing sector's investors pay more attention to these infrastructural capitals than the services sector's investors.

Omezzine and Hakro (2011) carried out a study on the link between FDI flows and governance infrastructure in Mena Region countries to investigate the extent to which governance infrastructure affects FDI inflows to North African and Middle East countries. Using data collected from UN Statistical Yearbooks, World Investment Reports and World Bank, they discovered that governance infrastructure has a significant positive impact on FDI flows to the regions. It was also found that improvement in governance increases the returns on investments.

The empirical study carried out by Rehman et al (2011) on the impact of infrastructure on FDI in Pakistan over the period between 1975 and 2008. The study examined the roles infrastructure play in attracting FDI and investigated the effects of exchange rate, market size and availability of infrastructure on FDI inflow to Pakistan. The result reveals that infrastructure plays an important role in attracting foreign direct investment into Pakistan both in the short-run and in the long-run.

Asiedu (2002) investigated the determinants of FDI in 70 developing countries, 35 of which are from SubSahara Africa region, for the period between 1988 and 1997 using OLS estimation technique. The results of the estimation revealed that infrastructural development, economic openness and high return on investment are key to attracting FDI. He opined that the geographical location of Sub-Sahara Africa countries is disadvantageous for FDI attraction.

Anyadike (2012), in his study, examined the extent to which poor infrastructure repels foreign investment and hinders economic growth in Nigeria between the period 2000 and 2010 . He identified poor infrastructural base as the primary cause of the low and meagre foreign investment in Nigeria. He specifically pointed at the deplorable states of road networks, energy generation, limited skilled manpower and insecurity as the bane of FDI inflow to Nigeria. He asserted that there is a high level of infrastructural decadence which has really discouraged investors from investing in Nigeria.

Essia and Onyema (2012) examined the factor influencing FDI inflow to Nigeria using primary data sourced from foreign firms in Nigeria. He discovered that attracting FDI calls for major reforms in areas like energy supply, improvements in infrastructures for transportation and communication, and maintaining flexible institutional frameworks which are responsive to investors' needs without compromising national interests.

Babatunde (2011), with the aid of panel data on Sub-Saharan African countries between the period 1980 and 2003, investigated if there exists any relationship between infrastructure, trade openness, FDI and economic growth. The results show that volume of FDI inflows depends on the extent of trade openness and GDP per capita. Further results show that FDI and economic growth has a significant positive relationship and that the interaction between trade openness and infrastructure increases FDI inflow slightly.

Wheeler and Mody (1992), in their famous study, examined the impact of infrastructure quality on investment in 42 developing countries over the period between 1982 and 1988. The result of the estimation of their translog specification shows that the quality of energy, communication and transport infrastructures have a highly significant positive impact on the volume of investment in the countries under study. In other words, one of the most important factors the United States considers before investing in developing countries is the quality of their infrastructure but for developed countries, it is not considered because countries adjudged developed possess high quality infrastructures.

\section{Data and Methodology}

This empirical study uses annual data from 1981 to 2014 to investigate the impacts infrastructure have on foreign direct investment inflow to Nigeria. The infrastructures to be examined in this study include: electric power production/generation, agricultural machinery (tractor), fixed telephone subscription which will proxy for telephone lines. The choice of these infrastructures is predicated on the fact that they are the major infrastructures that drive production in the key sectors of the Nigerian economy. For instance, electric power supply is crucial for efficiency in the manufacturing sector, tractors are instrumental to production in the agricultural sector and telephone lines are pivotal to the services sector output. 
Data used in this study were sourced from World Development Indicator (WDI). For the purpose of analysis, the natural logarithm of each of the variables is taken to neutralise the unit effect and also to make interpretation in proportionate terms. To prevent spurious regression, this study determines the level of stationarity of the time series data using Augmented Dickey Fuller (ADF) and Phillip Perron Unit Root test approach. The Autoregressive Distributed Lag (ARDL) framework is employed to determine the long-run relationship between FDI and infrastructure in Nigeria and the impact of infrastructure on the inflow of FDI to Nigeria. In view of this, the basic model employed in the study can be expressed as:

$\mathrm{LFDI}_{\mathrm{t}}=\beta_{1}+\beta_{2} \mathrm{LELPD}_{\mathrm{t}}+\beta_{3} \mathrm{LFTS}_{\mathrm{t}}+\beta_{4} \mathrm{LTRCT}_{\mathrm{t}}+\mu_{\mathrm{t}}$

Where:

LFDI $=$ Log of Foreign Direct Investment

LELPD $=$ Log of Electricity Production $(\mathrm{KwH})$

LFTS $=$ Log of Fixed Telephone subscriptions (per 100 people)

LTRCT $=$ Log of Tractors per $100 \mathrm{sq} . \mathrm{km}$ of arable land

An ARDL representation of equation (I) above is specified in equation (II) below:

$\Delta F D I_{t}=\alpha_{0}+\sum_{i=1}^{n} \alpha_{1 i} \Delta L F I_{t-i}+\sum_{i=0}^{n} \alpha_{2 i} \Delta L L P R D_{t-i}+\sum_{i=0}^{n} \alpha_{3 i} \Delta F T S_{t-i}+\sum_{i=0}^{n} \alpha_{4 i} \Delta L T R C T_{t-i}+\beta_{2} L E L P R D_{t}+\beta_{3} L F T S_{t}+\beta_{2} L_{T R C T}+\varepsilon_{t}$

where $\Delta$ denotes the first difference operator, $\alpha_{0}$ is the drift component, and $\varepsilon_{\mathrm{t}}$ is the white noise residuals

\section{Empirical Results}

\subsection{Unit Root Test}

It is a standard practice to carry out unit root test for macroeconomic variables to help examine their stationarity state and thereby prevent spurious results. Thus, this study employs the Augmented Dickey-Fuller (ADF) and Phillip Perron (PP) approach to unit root to test the stationarity state of the variables.

Although unit root test is not required in Autoregressive Distributed Lag (ARDL) framework, it is necessary to test for unit root to ensure that no variable in the model is found to be stationary after second difference, that is, I(2) because ARDL procedure does not accommodate I(2) series. Pesaran et al. (2001) and Narayan (2005) assert that the computed F-Statistics from the estimation of a model with I(2) variables using ARDL approach will not be valid and reliable.

Table 1 below show that using the Augmented Dickey Fuller (ADF) approach to unit root, all the variables are stationary at level except the log of electricity production which is stationary after the first difference. On the other hand, the result of the Phillip Perron (PP) approach shows that log of foreign direct investment and log of tractor per 100 sq. $\mathrm{km}$ of arable land are stationary at level while log of electricity production and log of fixed telephone subscription are stationary at first difference.

Based on this result, it is obvious that these variables are integrated of different orders. Thus, the Autoregressive Distribution Lag (ARDL) Bounds test will be employed to investigate whether there is a long-run relationship among the variables incorporated in our model.

Table 1: Summary of Unit Root Test

\begin{tabular}{|l|l|l|l|l|l|l|}
\hline \multirow{2}{*}{ Variables } & \multicolumn{3}{|c|}{ Augmented Dickey Fuller } & \multicolumn{3}{c|}{ Phillip Perron } \\
\cline { 2 - 7 } & Level & $\begin{array}{l}\text { First } \\
\text { Difference }\end{array}$ & $\begin{array}{l}\text { Order of } \\
\text { Integration }\end{array}$ & Level & $\begin{array}{l}\text { First } \\
\text { Difference }\end{array}$ & $\begin{array}{l}\text { Order } \\
\text { Integration }\end{array}$ \\
\hline LELPD & $-2.836621 \mathrm{~b}$ & $-6.547650 \mathrm{a}^{*}$ & $\mathrm{I}(1)$ & $-2.833689 \mathrm{~b}$ & $-6.683757 \mathrm{a}^{*}$ & $\mathrm{I}(1)$ \\
\hline LFDI & $-4.478002 \mathrm{~b}^{*}$ & $-10.78779 \mathrm{c}^{*}$ & $\mathrm{I}(0)$ & $-4.427060 \mathrm{~b}^{*}$ & $-10.31023 \mathrm{c}^{*}$ & $\mathrm{I}(0)$ \\
\hline LFTS & $-5.171080 \mathrm{~b}^{*}$ & $-3.296270 \mathrm{a}^{* *}$ & $\mathrm{I}(0)$ & $-1.285974 \mathrm{a}$ & $-1.959587 \mathrm{c}^{* *}$ & $\mathrm{I}(1)$ \\
\hline LTRCT & $-4.428800 \mathrm{a}^{*}$ & $-6.028332 \mathrm{~b}^{*}$ & $\mathrm{I}(0)$ & $-4.737311 \mathrm{a}^{*}$ & $-5.631615 \mathrm{~b}^{*}$ & $\mathrm{I}(0)$ \\
\hline
\end{tabular}

Source: Author's Computation using Eviews9

Note: $\quad *$ and $* *$ imply statistical significance at 1 percent and 5 percent respectively.

$\mathrm{a}, \mathrm{b}$ and c imply model with intercept, trend and intercept, and none respectively.

$\mathrm{I}(0)$ and $\mathrm{I}(1)$ imply that the time series is stationary at level and first difference respectively.

\subsection{Autoregressive Distributed Lag (ARDL) Bounds Test Approach to Cointegration}

Sequel to the result of the unit root test, cointegration test will be carried out using ARDL Bounds Test approach to cointegration. The choice of this approach is premised on the fact that our variables are integrated of different orders [(I(0) and I(1)], thus negating the use of Engle-granger and Johansen Cointegration test approach. Pesaran and Shin (1999) and Pesaran et al (2001) developed the ARDL cointegration approach which has three major advantages over other traditional cointegration approaches. Firstly, the ARDL framework does not require that all the variables under study be of the same order of integration; it accommodates series which are $\mathrm{I}(0)$ or $\mathrm{I}(1)$ or both. Secondly, it is relatively more efficient using small sample sizes. Thirdly, the ARDL framework obtains unbiased estimates of the long-run model (Harris and Sollis, 2003). 
Cointegration test is carried out to determine the existence of a long-run relationship between the dependent and explanatory variables. The rule of ARDL Bounds test of cointegration states that the null hypothesis should be rejected if the value of the computed F-statistic is greater than the upper bounds value and accepted if the Fstatistic is less than the lower bounds value. The ARDL cointegration test will be said to be inconclusive should the computed F-statistic fall within the lower and upper bound.

The result of ARDL Bound Test is presented in table 2 below. The result shows that the null hypothesis of no cointegration among the variables should be rejected since the value of the computed F-statistic (4.71) is greater the upper bound critical value of 4.35 at 5 percent level of significance. This implies that there is a long-run relationship among the dependent variable (LFDI) and the explanatory variables. Since the variables of the model are cointegrated, we will proceed to estimating the ARDL Error Correction Model (ECM).

Table 2: Result of ARDL Bounds Test Approach to Cointegration

\begin{tabular}{|c|c|c|c|}
\hline \multirow{2}{*}{$\begin{array}{l}\text { Variables } \\
\text { F(LFDI/ ELPRD, LFTS, LTRCT) }\end{array}$} & \multicolumn{2}{|c|}{ Critical Value } & \multirow{2}{*}{$\begin{array}{l}\text { Computed F- } \\
\text { Statistics }\end{array}$} \\
\hline & Lower Bound & Upper Bound & \\
\hline 1\% Significance Level & 4.29 & 5.61 & $4.71 * *$ \\
\hline $5 \%$ Significance Level & 3.23 & 4.35 & \\
\hline $10 \%$ Significance Level & 2.72 & 3.77 & \\
\hline
\end{tabular}

** indicates that computed statistic falls above the upper bounds value at 5 percent significance level. The Schwarz Criterion selected the optimal lag length $(\mathrm{k}=2)$. The Bounds critical values are obtained from Narayan $(2005)$ case III for 40 observations.

Source: Author's Computation using Eviews9

Since the empirical findings lead to the conclusion that there is a long run relationship among the variables in our model, the marginal impacts of electricity production, telephone lines and tractors on foreign direct investment in Nigeria is examined by estimating equation (II) for the short-run (ECM) and long-run coefficients of the ARDL $(2,1,0,0)$ model selected using the Schwarz Criterion (SC). The result of the estimation is presented in Table 3.

The result of the estimation of the long-run coefficient of equation (II) shows that, in the long run, electricity production has a positive and significant influence on the inflow of foreign direct investment to Nigeria such that a one percent increase electricity production will lead to approximately 2.48 percent increase in foreign direct investment (FDI). The result also shows that, in the long run, a one percent increase in telephone lines and tractor will lead to approximately 0.01 percent and 0.66 percent decline in the inflow of foreign direct investment to Nigeria respectively. However, telephone lines and tractors do not have significant effect in attracting FDI to Nigeria in the long run.

Table 3: Estimated Long-Run Coefficients of ARDL $(2,1,0,0)$ Model

Dependent Variable: LFDI

\begin{tabular}{lllll}
\hline \hline Variable & Coefficient & Std. Error & t-Statistic & Prob. \\
\hline \hline LELPD & 2.484690 & 0.673340 & 3.690100 & 0.0011 \\
LFTS & -0.005189 & 0.185082 & -0.028038 & 0.9779 \\
LTRCT & -0.657772 & 1.044494 & -0.629752 & 0.5346 \\
C & 1.475396 & 18.059173 & 0.081698 & 0.9355 \\
\hline \hline
\end{tabular}

Source: Author's Computation using Eviews9

The result of the estimation of the short-run coefficient from the error correction model (ECM) version of the selected ARDL $(2,1,0,0)$ model is presented in Table 4 . The result shows that the error correction term is negative and significant at 1 percent thereby validating the existence of a stable long-term relationship among the variables of the model. The error correction coefficient $(-0.84)$ reveals that the speed of adjustment from a short-run deviation is quite fast as approximately 84 percent of the disequilibrium in foreign direct investment resulting from the shock in the previous period will converge to the long-run equilibrium in the current period. Furthermore, the result shows that the estimated coefficient of first-period lag of FDI has a negative and significant relationship with FDI in the short run. Also, there is a positive relationship between electricity production and FDI in the short run such that a one percent increase in electricity production leads to approximately 0.92 percent increase in FDI. This result is plausible and in consonance with Essia and Onyema (2012) and Anyadike (2012) because the availability of power supply reduces cost of production and increases investors' profit. An inverse relationship exists between telephone lines and FDI such that a one percent increase in the former discourages foreign investor from investing in Nigeria by reducing the volume of FDI by approximately 0.01 percent. Also, an inverse relationship was found to exist between tractor and FDI in the short-run such that a one percent increase in number of tractors used in agriculture will lead to a 0.55 percent decline in FDI. This result is plausible in that the oil and 
service sector are the targets and destinations of foreign investors because they are the booming sectors of the Nigerian economy. However, the result shows that electricity production, telephone lines and tractors do not have significant effect on the attraction of FDI into Nigeria. In addition, the adjusted R-Squared value shows that the model explains about 88 percent of the variation in FDI. Also, the probability value of the F-Statistic shows that the explanatory variables in the model jointly influence the volume of FDI inflow to Nigeria in the short-run. The Durbin-Watson Statistic shows the absence of autocorrelation in the model.

Table 4: Error Correction Representation for the Selected ARDL $(2,1,0,0)$ Model

\section{Dependent Variable: LFDI}

\begin{tabular}{cccrr}
\hline \hline Variable & Coefficient & Std. Error & t-Statistic & Prob. \\
\hline \hline D(LFDI(-1) & -0.294687 & 0.141498 & -2.082613 & 0.0477 \\
D(LELPD) & 0.916480 & 0.814477 & 1.125237 & 0.2712 \\
D(LFTS) & -0.004358 & 0.155572 & -0.028015 & 0.9779 \\
D(LTRCT) & -0.552433 & 0.881618 & -0.626613 & 0.5366 \\
ECM(-1) & -0.839856 & 0.164406 & -5.108417 & 0.0000
\end{tabular}

$\mathrm{ECM}=$ LFDI $-(2.4847 *$ LELPD $-0.0052 *$ LFTS $-0.6578 *$ LTRCT + 1.4754$)$

R-Squared $=0.9011 \quad$ Adjusted R-Squared $=0.8774$

F-Statistic $=37.977(0.0000) \quad$ Durbin-Watson Stat $=2.1131$

Short-Run Diagnostic Tests

Serial Correlation LM Test $=3.9986(0.1354)$

Heteroscedasticity Test $(\mathrm{ARCH})=1.4066(0.4949)$

Normality Test $=3.5646(0.1683)$

Ramsey RESET Test $=1.4061(0.2654)$

Table 4 also presents the result of the short-run diagnostic test of the selected ARDL model. For the result of this estimation to be accepted, none of the assumptions of Ordinary Least Square (OLS) must be violated hence, the need for diagnostic tests. This study tests for serial correlation, heteroscedasticity, specification form and normal distribution of the estimated model. The result reveals that the estimated model passed all diagnostic tests. The results show the absence of autocorrelation and heteroscedasticity in the model and it is also normally distributed and correctly specified.

Lastly, the stability of the long-run coefficient and the short-run movements for the ARDL Error Correction Model is examined using the Cumulative Sum (CUSUM) and Cumulative Sum Squares (CUSUMSQ). The rule is that if the plots of the CUSUM and CUSUMSQ statistics stay within the critical bounds of 5 percent significance level, the model is said to be stable. In line with this condition, a critical look at the plots in Figure 1 and 2 below shows that the ARDL Error Correction Model is stable because the CUSUM and CUSUMSQ statistics fall within the $5 \%$ critical bounds.

Plot of CUSUM and CUSUMSQ (Stability Test)

Figure 1: Plot of Cumulative Sum of Recursive Residuals

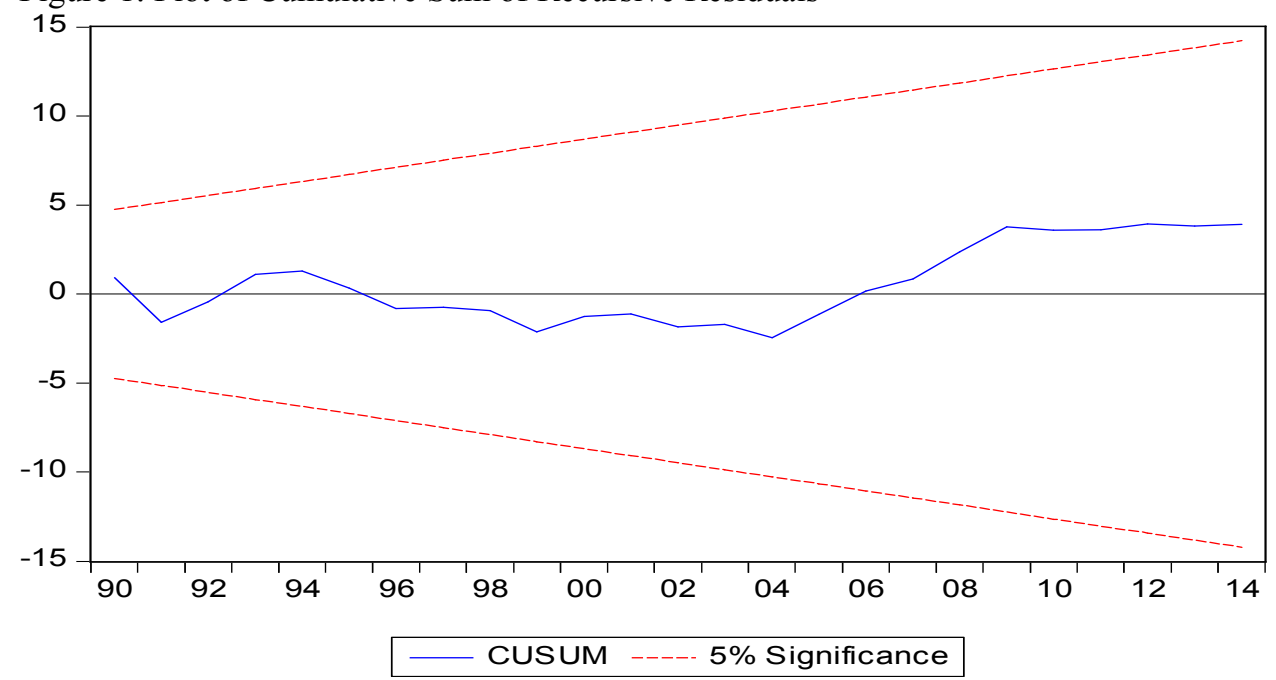


Figure 2: Plot of Cumulative Sum of Squares of Recursive Residuals

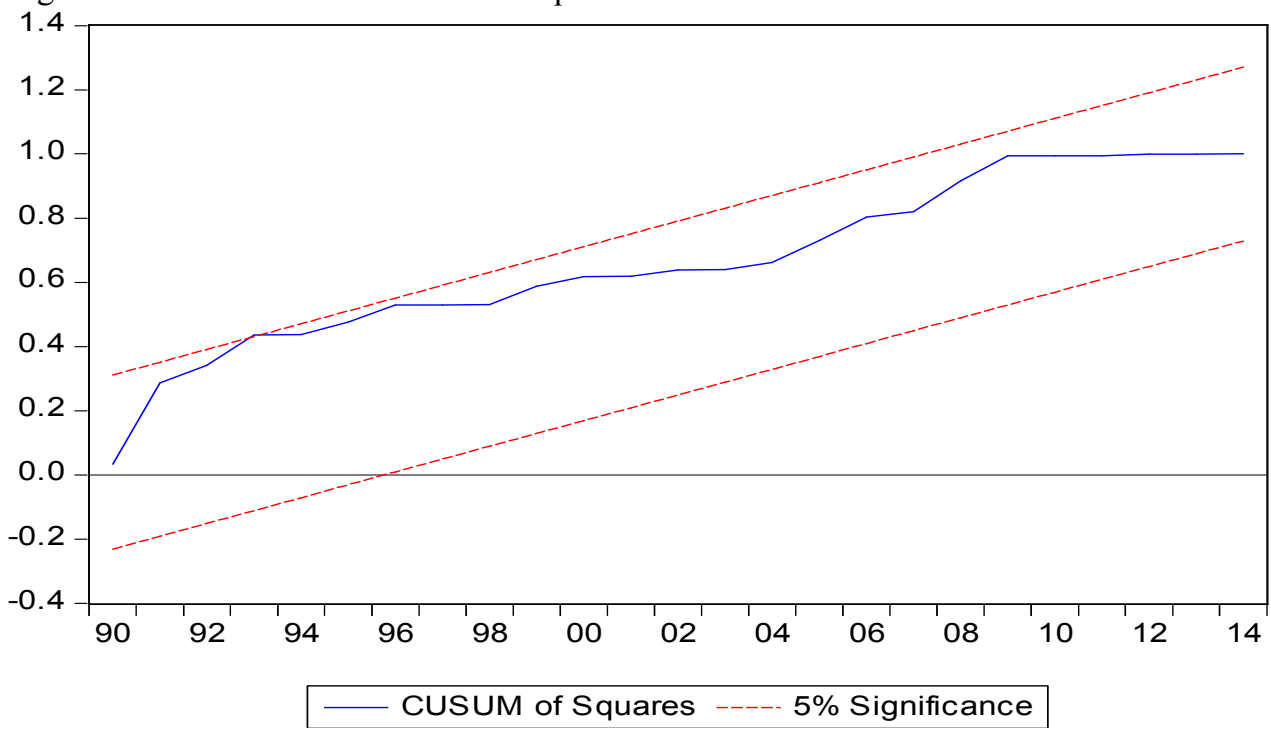

5.0 Conclusion and Policy Recommendations

This study examined the impact infrastructure on foreign direct investment inflow to Nigeria using Autoregressive Distributed Lag (ARDL) framework. The infrastructures considered in this study are electricity production, telephone lines and tractors which are important drivers of output in the manufacturing, services and agricultural sector respectively. The results of the unit root test show that none of the variables is integrated of order two, I (2) which justifies the use of ARDL Bound Test approach to cointegration and the estimation of long-run and shortrun ARDL model. The result of the cointegration test shows that the long-run relationship exists among the variables in the ARDL model as the computed F-statistic is greater that the upper bound critical value at 5 percent significance level. The result of the long-run coefficient reveals that only electricity production has a positive and significant impact on FDI in the long-run which implies that electricity production plays a significant role in attracting foreign direct investment to Nigeria. However, none of the infrastructure variables has significant effect on FDI inflow in the short-run. Diagnostic and stability test results show that the model is stable and does not violate any of the OLS assumptions of homoscedaticity, no serial correlation and normality of residuals.

The significant impact electricity has in attracting FDI to Nigeria in the long run shows that the Nigerian government and the private sector should gear efforts towards resuscitating the ailing power sector, standardizing it and devising others means of generating alternative power supply so as to realize the goal of becoming one of the leading twenty economies in the world by the year 2020. Due to the pivotal role power (electricity) supply plays as a propeller of the FDI and economy growth, it should be given adequate attention and preference. Also, international donor agencies like UNO, Paris Club, World Bank, IMF and Nigeria's friend countries, among others, should focus primarily on developing the Nigerian power sector.

\section{References}

Adeoye, A. (2009). Macro-Economic Level Corporate Governance and FDI in Emerging Markets: Is There a Close Relationship? Journal of Economics and International Finance, Vol. 1, (12) 030-043.

Anyadike, N. O. (2012). Poor Infrastructure: The Hindrance to Foreign Investment and Economic Development in Nigeria. Interdisciplinary Journal of Contemporary Research in Business, Vol 4, No 4.

Asiedu, E. (2002). On the Determinants of Foreign Direct Investment to Developing Countries: Is Africa Different? World Development, 30 (1) 107-119.

Babatunde, A. (2011). Trade Openness, Infrastructure, FDI and Growth in Sub-Saharan African Countries. Journal of Management Policy and Practice, Vol. 12(7)

Behname, M. (2012). Foreign Direct Investment and Urban Infrastructure: An Evidence from Southern Asia. Advances in Management \& Applied Economics, Vol. 2, No.4, 253-259

Bénassy-Quéré, A. et al (2007). Tax and Public Input Competition. Economic Policy, 22: 385-430.

Chakrabarti, R., Subramanian, K., Meka, S. and Sudershan, K. (2012). Infrastructure and FDI: Evidence from district-level data in India. Retrieved from http://www.isb.edu/faculty/KrishnamurthySubramanian/Images/FDI_infra_20Mar2012_ReStud.pdf

Cohen, S.D. (2007). Multinational Corporations and Foreign Direct Investment, Oxford University Press.

Erenberg, S. J. (1993). The real effects of public investment on private investment. Applied Economics, 23, 831837. 
Essia, U. and Onyema, J. (2012). Determinants of Foreign Direct Investment in Nigeria. Journal of Money, Investment and Banking, ISSN 1450-288X Issue 25.

Fung, K., Garcia-Herrero, A. and Ng, F. (2005). Hard or Soft? Institutional Reforms and Infrastructure Spending as Determinants of Foreign Direct Investment in China. Japanese Economic Review, 56(4), 408-416.

Hakro, A.N. and Omezzine, A.M. (2011). Governance Infrastructure and FDI Flows in Mena Region Countries. Middle Eastern Finance and Economics, - Issue 12.

Harris, R. and Sollis, R. (2003). Applied Time Series Modelling and Forecasting. Wiley, West Sussex

Hill, C.W.L. (2003). Global Business. McGraw-Hill Irwin.

Narayan, P.K. (2005). The Saving and Investment Nexus for China: Evidence from Cointegration Tests. Applied Economics, 37:17

Obiwona, M. B. (2001). Determinants of FDI and their Impact on Economic Growth in Uganda. African Development Review, 13, 46-81.

Pesaran M.H. and Smith R.P. (1985). Evaluation of Macroeconometric Models. Economic Modelling, 2(2): $125-$ 34

Pesaran, M. and Shin, Y. (1999). An Autoregressive Distributed Lag Modelling Approach to Cointegration Analysis, in S. Strom, (ed) Econometrics and Economic Theory in the 20th Century: The Ragnar Frisch centennial Symposium, Cambridge University Press, Cambridge.

Rehman, A., Ilyas, M., Alam, H.M. and Akram, M. (2011). The Impact of Infrastructure on Foreign Direct Investment: The Case of Pakistan. International Journal of Business and Management, Vol. 6, No. 5

Seetanah, B. (2009). A Sector-Wise Panel Data Study on the Link between Transport Infrastructure and FDI in Mauritius. 9th Global Conference on Business \& Economics, ISBN: 978-0-9742114-2-7

Wheeler D. and Mody A. (1992). International Investment Location Decisions: The Case of U.S. Firms. Journal of International Economics, Vol.33, pp. 57-76.

World Development Indicators (2015), World Bank. 